\title{
Distinct Trophic Specializations Affect How Phytophthora ramorum and Clade 6 Phytophthora spp. Colonize and Persist on Umbellularia californica Leaves in Streams
}

\author{
Kamyar Aram ${ }^{\dagger}$ and David M. Rizzo
}

Department of Plant Pathology, University of California, One Shields Drive, Davis 95616. Accepted for publication 12 February 2018.

\begin{abstract}
Phytophthora spp. are regularly recovered from streams but their ecology in aquatic environments is not well understood. Phytophthora ramorum, invasive in California forests, persists in streams at times when sporulation in the canopy is absent, suggesting that it reproduces in the water. Streams are also inhabited by resident, clade 6 Phytophthora spp., believed to be primarily saprotrophic. We conducted experiments to determine whether differences of trophic specialization exist between these two taxa, and investigated how this may affect their survival and competition on stream leaf litter. $P$. ramorum effectively colonized fresh (live) rhododendron leaves

all leaf types. However, both taxa were recovered from naturally occurring California bay leaf litter in streams. In stream experiments, P. ramorum colonized bay leaves rapidly at the onset; however, colonization was quickly succeeded by clade 6 species. Nevertheless, both taxa persisted in leaves over 16 weeks. Our results confirm that clade 6 Phytophthora spp. are competent saprotrophs and, though $P$. ramorum could not colonize dead tissue, early colonization of suitable litter allowed it to survive at a low level in decomposing leaves.
\end{abstract} but not those killed by freezing or drying, whereas clade 6 species colonized
Additional keywords: decay, oomycetes, pathogen.
Phytophthora is a genus of the fungal-like oomycetes containing species that have long been recognized as causes of destructive and recalcitrant plant diseases in many cropping systems worldwide (Erwin and Ribeiro 1996). In recent decades, they have increasingly gained notice as causes of epidemics and considerable ecological disturbance in more or less natural environments (Hansen 2008; Hansen et al. 2012). Notable among these are Phytophthora ramorum Werres, de Cock \& Man in't Veld, cause of sudden oak death (SOD) in the western United States (Rizzo et al. 2005) and of sudden larch death in the United Kingdom (Brasier and Webber 2010), and P. alni sensu latu, cause of decline of alders throughout Europe (Bjelke et al. 2016; Brasier et al. 2004; Jung and Blaschke 2004; Jung et al. 2007), among a number of other species associated with forest and other wildland diseases throughout the world (Balci and Halmschlager 2003a,b; Balci et al. 2007; Brasier et al. 2005; Greslebin and Hansen 2010; Greslebin et al. 2005; Hansen and Delatour 1999; Jung et al. 1999, 2000; Vettraino et al. 2001). These recent cases greatly expand the previously recognized cases of "forest Phytophthoras" such as $P$. cinnamomi in Australia (O'Brien and Hardy 2014) and P. lateralis in the northwestern United States (Jules et al. 2015). As a consequence of research focused on Phytophthora spp. in these nonagricultural environments, a surprising diversity and abundance of species have been discovered, many previously undescribed (Hansen et al. 2012; Kroon et al. 2012). Lotic and riparian ecosystems are particularly

${ }^{\dagger}$ Corresponding author: K. Aram; E-mail: kamaram@ucdavis.edu

Funding: This work was supported by funding from United States Department of Agriculture U.S. Forest Service, Pacific Southwest Research Station and Forest Health Protection, State and Private Forestry, and the Gordon and Betty Moore Foundation.

*The $\boldsymbol{e}$-Xtra logo stands for "electronic extra" and indicates that two supplementary figures and eight supplementary tables are published online.

(c) 2018 The American Phytopathological Society abundant with Phytophthora spp., many of which are now considered resident and characteristic of such environments (Brazee et al. 2016; Dunstan et al. 2016; Hansen et al. 2012; Huai et al. 2013; Hwang et al. 2011, 2010; Jung et al. 2011; Nagel et al. 2015; Oh et al. 2013; Reeser et al. 2011; Shrestha et al. 2013; Sims et al. 2015; Stamler et al. 2016). Foremost among these are $P$. gonapodyides (H. E. Peterson) Buisman and other closely affiliated species in clade 6 of the genus (Brasier et al. 2003a; Cooke et al. 2000), which are regularly and widely reported in stream surveys (Hansen and Delatour 1999; Hansen et al. 2012; Jung et al. 2011; Murphy et al. 2005; Nechwatal and Mendgen 2006; Oh et al. 2013; Parke et al. 2014; Pérez-Sierra et al. 2013; Reeser et al. 2011; Sims et al. 2015; Sutton et al. 2009; Themann et al. 2002; Vettraino et al. 2001). Nevertheless, many species associated with plant disease are also regularly reported from natural streams as well as irrigation canals and reservoirs associated with crop fields and nurseries (Bush et al. 2003; Chastagner et al. 2010; Ghimire et al. 2011; Greslebin et al. 2005; Hong et al. 2010; Hong et al. 2012; Hüberli et al. 2013; Hulvey et al. 2010a; Hwang et al. 2010; Jung and Blaschke 2004; Nagel et al. 2015; Oh et al. 2013; Oudemans 1999; Parke et al. 2014; Reeser et al. 2011; Roberts et al. 2005; Sutton et al. 2009; Themann et al. 2002; Werres et al. 2007; Yang and Hong 2014).

Though the occurrence of Phytophthora spp. in surface waters is now widely documented, there has been little investigation of their ecology in such ecosystems (Hansen et al. 2012; Marano et al. 2016). Although many taxa that are both widespread and putatively native in streams are assumed to be saprotrophs subsisting on decaying vegetation (Brasier et al. 2003a; Hansen and Delatour 1999; Hansen et al. 2012; Marano et al. 2016, 2010; Reeser et al. 2011), the ecological implications of the occurrence in streams of Phytophthora spp. known as pathogens has received less consideration. In general, there is limited overlap of Phytophthora spp. found in natural environments and those occurring in agricultural settings (Hansen et al. 2012). Species found in ornamental plant nurseries bridge this gap to some extent because many significant pathogens of forests and natural environments are suspected to have originated from nurseries (Brasier 2008; Brasier et al. 2004, 2005; 
Croucher et al. 2013; Jung 2009; Jung et al. 2007; Mascheretti et al. 2008; Moralejo et al. 2009; Prospero et al. 2009; Rizzo et al. 2005) and many typically aquatic species, such as $P$. gonapodyides and $P$. chlamydospora, are considered to be facultative pathogens, especially in nursery settings (Hansen et al. 2012, 2015; Navarro et al. 2015; Parke et al. 2014; Sims et al. 2015; Yakabe et al. 2009).

For some pathogenic Phytophthora spp., such as $P$. alni sensu lato and $P$. lateralis, the abundance of propagules in streams is clearly associated with infections on submerged roots of their riparian hosts (Bjelke et al. 2016; Hansen et al. 2000; Jung and Blaschke 2004; Strnadová et al.2010). A similar association has not been observed for $P$. ramorum, which is primarily a foliar pathogen and yet is often remarkably abundant in streams in California forests where it is established in the canopy, even when conditions are not conducive to sporulation (Murphy et al. 2005). P. ramorum also often persists for years after known terrestrial inoculum sources have been eradicated or otherwise in the absence of detectable plant infections (Chastagner et al. 2011, 2010; Sutton et al. 2009; Turner et al. 2008). Therefore, it appears that the occurrence of $P$. ramorum in streams is not merely a consequence of terrestrial inoculum run-off or the introduction of infected leaves into the stream but also that the pathogen has an aquatic cycle that increases inoculum in streams. The possibility of an aquatic disease cycle for $P$. ramorum is important with respect to evaluating and managing its potential spread.

$P$. ramorum is an introduced and invasive organism in the forest ecosystems of western North America, where its impact has been well documented (Grünwald et al. 2008; Rizzo et al. 2005). The introduction of $P$. ramorum into stream habitats implies its potential competition with abundant, resident, clade 6 Phytophthora spp. (Hansen et al. 2012; Murphy et al. 2005; Reeser et al. 2011). This co-occurrence of $P$. ramorum with clade 6 Phytophthora spp. in forest streams affords an opportunity to study the interaction of an exotic mycelial organism with putatively native ones, a phenomenon generally little investigated (Rizzo 2005). Furthermore, the ecology of clade 6 Phytophthora spp. has not been experimentally investigated, and their saprotrophic lifestyle has been only inferred from their regular recovery from decaying vegetation (Brasier et al. 2003a; Hansen and Delatour 1999; Hansen et al. 2012; Jung et al. 2011; Marano et al. 2016, 2010; Nagel et al. 2015; Nechwatal et al. 2013; Reeser et al. 2011).

Vegetative litter is the primary source of nutrients for microorganisms in stream ecosystems (Bärlocher and Boddy 2016; Gessner et al. 1999; Wallace et al. 1999). Just as Phytophthora spp. infect bait leaves in streams, leaf and other vegetative litter in aquatic environments can serve as a substrate for their survival. The biology of Phytophthora, regarded as a genus of well-adapted hemibiotrophic plant pathogens with a necrotrophic phase (Erwin and Ribeiro 1996; Hardham and Blackman 2010), suggests that their ecological role in leaf decomposition should be early colonization and breakdown of relatively fresh, live vegetative tissue resistant to immediate penetration by saprobes. Organisms that penetrate and colonize newly shed leaves can open access to tissue for succession by other saprotrophic organisms (Frankland 1998). Nevertheless, most vegetative litter quickly degrades in the aquatic environment, and would presumably become unsuitable to organisms with a primarily parasitic rather than saprotrophic lifestyle. If clade 6 Phytophthora spp. are truly adapted as saprotrophs, they should be able to colonize and reproduce on decomposing vegetative matter. This raises the question as to how well P. ramorum, an organism clearly adapted as a plant pathogen, can compete for vegetative tissue among the abundance of saprotrophic organisms in streams. Understanding the capacity of these organisms to compete for vegetative litter is essential to understanding the ecology of resident and introduced Phytophthora spp. in streams.

California bay (Umbellularia californica (Hook. \& Arn.) Nutt.) is a common, broadleaf evergreen component of northern California's coastal forests and a frequently occurring tree species in riparian zones (Rundel and Sturmer 1998; Shreve 1927). It is also a primary source of
P. ramorum inoculum in SOD-affected California forests (Rizzo et al. 2005) and, therefore, along with tanoak (Notholithocarpus densiflorus (Hook. \& Arn.) Manos, Cannon \& S. Oh), one of the two hosts that drive epidemics. Though California bay leaves are highly conducive to sporulation by $P$. ramorum, the pathogen causes negligible damage to this tree species (Davidson et al. 2005, 2008; DiLeo et al. 2009). Additionally, California bay is sclerophyllous (Cooper 1971), as is typical for broadleaf evergreen plants in Mediterranean-type climates, and, therefore, its leaves decompose slowly. Thus, bay leaves are both very common as litter in northern California forest streams and also a highly suitable substrate for $P$. ramorum. Indeed, the presence of $P$. ramorum inoculum in streams has been associated with the presence of bay leaf litter (Tjosvold et al. 2008). In infested forests, a significant portion of the bay leaf canopy is infected with $P$. ramorum in late winter and early spring, when storms are active and can cause leaves to be shed into streams (Davidson et al. 2011; DiLeo et al. 2014; Eyre et al. 2013). It is possible that $P$. ramorum may enjoy an advantage relative to stream-inhabiting microorganisms in further colonizing leaves that were already infected in the canopy after they are shed into streams (e.g., Voříšková and Baldrian 2013). Additionally, the efficacy of $P$. ramorum as a pathogen may allow its streamborne inoculum to colonize fresh leaf tissue before saprotrophic organisms can penetrate the tissue.

In light of this ecological picture, the goals of this study were to (i) assess any differences in the trophic abilities of $P$. ramorum and clade 6 Phytophthora spp. (particularly $P$. gonapodyides) with respect to live and dead leaf tissue, (ii) survey the colonization of naturally occurring California bay leaf litter in streams where both $P$. ramorum and clade 6 Phytophthora spp. are prevalent, (iii) determine how well these Phytophthora taxa could colonize newly exposed bay leaves in streams and how well they could survive as leaves decompose, and (iv) determine whether precolonization of leaves by $P$. ramorum gives it an advantage in colonizing and persisting on bay leaves.

\section{MATERIALS AND METHODS}

Study sites. We conducted field experiments in two perennial second-order streams (generally 2 to $3 \mathrm{~m}$ wide and less than $1 \mathrm{~m}$ deep) at nearby locations approximately $5 \mathrm{~km}$ apart on the east and west slopes of Sonoma Mountain in Sonoma County, CA, where $P$. ramorum was well established in the forest canopy (Davidson et al. 2005, 2008; DiLeo et al. 2014; Maloney et al. 2005), and both $P$. ramorum and clade 6 Phytophthora spp. were regularly recovered by baiting from streams. Graham Creek at Jack London State Historic Park $\left(38^{\circ} 21^{\prime} 2^{\prime \prime} \mathrm{N}, 122^{\circ} 33^{\prime} 16^{\prime \prime} \mathrm{W}\right)$ runs through primarily redwood forest, with California bay as a dominant riparian tree along with redwood (Sequoia sempervirens), Douglas fir (Pseudotsuga menziesii), tanoak, big leaf maple (Acer macrophyllum), and less frequently, madrone (Arbutus menziesii). Copeland Creek at Sonoma State University's Fairfield Osborne Preserve $\left(38^{\circ} 20^{\prime} 37^{\prime \prime} \mathrm{N}, 122^{\circ} 35^{\prime} 41^{\prime \prime} \mathrm{W}\right)$ passes through primarily mixedevergreen forest with a predominance of bay, white alder (Alnus rhombifolia), big leaf maple, and, occasionally, tanoak, madrone, and coast live oak (Quercus agrifolia). Both sites are subject to a Mediterranean-type climate, with mild, moist winters and dry summers. The mean annual temperature and precipitation in the region are $15^{\circ} \mathrm{C}$ and $800 \mathrm{~mm}$, respectively (https://www.ncdc.noaa. gov). However, rainfall was especially low in 2013 (209 mm annual and $145 \mathrm{~mm}$ from January through August), when much of the field collecting and experimental work described here was performed.

Trophic specialization. To test whether Phytophthora ramorum could infect dead leaf tissue in streams where there would be competition from saprobes, including putatively saprotrophic clade 6 Phytophthora spp., we simultaneously exposed to natural stream inoculum fresh (live) greenhouse-grown Rhododendron leaves (cultivar Colonel Cohen), along with leaves killed by either overnight freezing $\left(-20^{\circ} \mathrm{C}\right)$ or oven drying $\left(95^{\circ} \mathrm{C}\right)$. At the sites 
described above, five bait leaves of each type were deployed at three pools in each stream, separated by at least $50 \mathrm{~m}$, held in flat mesh envelopes with slots sewn in to keep individual leaves separate, kept near the surface by an attached tubular float made from PVC pipe, and secured to the bank by a rope. Each month, from February through May in 2009 and 2010, a set of leaves was exposed for 10 to 24 days, with shorter intervals for warmer stream temperatures. Upon retrieval and transport to the laboratory in a chilled cooler, bait leaves were gently rubbed free of biofilm and debris in a 5\% household bleach solution (hypochlorite at $\sim 360 \mathrm{ppm}$ ) and surface sterilized in fresh bleach solution for $2 \mathrm{~min}$. They were then rinsed with deionized tap water and laid out on paper towels, and the excess water was allowed to evaporate. Finally, leaves were wrapped in a paper towel and stored at $4{ }^{\circ} \mathrm{C}$ until isolations by culturing could be performed, usually within 3 weeks. Isolations were attempted on PARP-H medium $(1.7 \%$ [wt/vol] corn meal agar, pimaricin at $5 \mathrm{ppm}$, ampicillin at $250 \mathrm{ppm}$, rifampicin at $10 \mathrm{ppm}$, pentachloronitrobenzene at $50 \mathrm{ppm}$, and hymexazol at $25 \mathrm{ppm}$ ) (Erwin and Ribeiro 1996) by sampling 6-mm leaf discs (using a standard hole punch) from necrotic lesions or, in the absence of distinct lesions (always the case with frozen or dried leaves), from the tip, center, and base at midrib as well as the petiole of each leaf. The presence of $P$. ramorum and clade 6 Phytophthora spp. was determined by microscopic examination of isolate morphologies directly from the isolation plates after 4 to 5 days at $18^{\circ} \mathrm{C}$ and checked again periodically for 3 weeks. Though these taxa have optimal growth above $20^{\circ} \mathrm{C}$, the slightly lower incubation temperature improves our recovery of $P$. nemorosa (Hansen et al. 2003), a species that we also encounter in California forest streams. $P$. ramorum is readily identified by short-branching coralloid hyphae and production of abundant chlamydospores in culture (Werres et al. 2001). Clade 6 Phytophthora spp., in contrast, form long, straight to slightly curved side branches with generally no survival structures at the temperature at which we incubated cultures (though $P$. chlamydospora forms chlamydospores above $22^{\circ} \mathrm{C}$ ) (Hansen et al. 2015). We have observed some clade 6 isolates to form irregularly shaped, pigmented hyphal swellings on PARP-H without hymexazol (PARP)-based media. Two other species are typically encountered in these forests: $P$. nemoros $a$ can be identified in PARP media by a diffuse rather than radiating pattern of growth, right-angled hyphal branching, and, eventually, production of dispersed oospores with amphigynous antheridia (Hansen et al. 2003); P. pseudosyringae produces radiating, coralloid hyphal growth in PARP media similar to $P$. ramorum but produces no chlamydospores, instead sometimes producing oospores with amphigynous or paragynous antheridia and occasional intercalary globose hyphal swelling chains (Jung et al. 2003) (though, in our experience, these are more consistently and abundantly produced in V8 juice-based media). $P$. nemorosa was recovered very rarely and $P$. pseudosyringae not at all in samples from these streams. Any Phytophthora or Pythium-like isolates not conforming to these as well as a subsample of morphologically identified isolates were saved for identification by sequencing of the internal transcribed spacer (ITS) genomic region (Aram 2017).

To determine whether $P$. ramorum was excluded from dead leaves due to lack of saprotrophic ability or from being outcompeted by clade 6 Phytophthora spp., we conducted a controlled experiment exposing live or dead leaves to $P$. ramorum and $P$. gonapodyides alone or in combined inoculations. We used a complete block design with a factorial of leaf condition by Phytophthora spp. inoculation treatment. An experimental unit consisted of a plastic cup $(120 \mathrm{ml}$ specimen collection type) of $100 \mathrm{ml}$ of deionized water in which were submerged to just below the petiole two fresh, frozen, or dried rhododendron leaves, prepared as above. We used a "cocktail" of two isolates of each Phytophthora spp., all recovered from the streams described above by baiting (P. ramorum isolates Pr-722 and Pr-726 and $P$. gonapodyides isolates P-559 and P-560, maintained in D. M. Rizzo's laboratory at the University of California-Davis). The inoculum consisted of a base rate of 100 sporangia per $100 \mathrm{ml}$ in one trial and a base rate of 1,000 zoospore cysts per $100 \mathrm{ml}$ in a second trial. The combined $P$. ramorum and $P$. gonapodyides inoculation received a base rate of each Phytophthora sp. and, thus, a doubled inoculum rate treatment was included for each species alone to control for a total inoculum rate effect. To produce sporangia, each isolate was separately cultured on a $20 \%$ clarified V8 agar $(1.7 \%$ [wt/vol] agar plus V8 original vegetable juice [Campbells Soup Co.] neutralized with $\mathrm{CaCO}_{3}$ at $15 \mathrm{~g} /$ liter, clarified by centrifuging at 7,000 rpm for $10 \mathrm{~min}$, and diluted with deionized water) and colonized 12-mm-diameter agar discs excised from the growing edge of cultures were transferred to 100 -mm-diameter Petri plates. The colonized agar discs were then flooded just to the upper surface with autoclaved soil extract (Erwin and Ribeiro 1996) and incubated for 2 days under ambient light and temperature. When sporangia were observed, the $P$. ramorum plates were agitated gently to loosen the sporangia, and the resultant suspension was filtered through several layers of cotton mesh (cheesecloth) and washed through with autoclaved deionized tap water. Sporangia suspensions for $P$. gonapodyides were similarly obtained, except that the surface of the mycelium growing from agar discs was gently scrubbed with a rubber policeman to knock off the noncaducous sporangia. Each suspension was quantified after thoroughly mixing by counting the number of sporangia in multiple $20 \mu \mathrm{l}$ samples. Zoospores were produced by chilling agar plugs with sporangia at $4^{\circ} \mathrm{C}$ for $1 \mathrm{~h}$, then returning them to room temperature. An abundance of zoospores were observed within $1 \mathrm{~h}$. Zoospores were induced to encyst by vortexing and the concentration of the suspensions was determined by repeated counts using a hemocytometer. Each suspension was put under constant stirring in a beaker and the appropriate volume to achieve the inoculum dose was added to each treatment. Experiments were maintained in growth chambers (model PGR-15; Conviron Controlled Environment, Ltd, ) at $18^{\circ} \mathrm{C}$ for 10 days with a $12 \mathrm{~h}$ photoperiod (approximately 1,800 lux), after which leaves were retrieved and surface sterilized, and isolations attempted from them. The incubation temperature used reflects the higher range that typically occurs in streams of coastal California during the season of peak detection from late winter to late spring. Both Phytophthora taxa focused on in this study grow at this temperature unimpeded (see discussion below for greater detail). Isolations were conducted as described above, except here we employed a mosaic sampling approach whereby leaf discs are removed from the midrib and flanking lobes of the leaf as well as the petiole at approximately $1 \mathrm{~cm}$ distance from one another in order to collect a representative sample from the entire leaf area (Supplementary Fig. S1) (based on Newell and Fell 1995). P. ramorum and $P$. gonapodyides were identified from morphological characteristics by microscopic examination of isolation plates, as described above.

Naturally colonized leaf litter. To evaluate Phytophthora colonization of naturally occurring litter in streams, submerged California bay leaves were collected from streams in January through April 2013 at the sites described above as well as from a creek at Samuel P. Taylor State Park ( $\left.38^{\circ} 1^{\prime} 11^{\prime \prime} \mathrm{N}, 122^{\circ} 43^{\prime} 47^{\prime \prime} \mathrm{W}\right)$ in Marin County, which was also surrounded by forest with established $P$. ramorum infestation (Maloney et al. 2005). This site also features a strong presence of bay in riparian areas, as is typical of $P$. ramorum-infested sites in California. Although we focused on bay leaf litter in the study, we also sampled leaves and other vegetative litter from other species when they were present in notable quantities (e.g., white alder, madrone, big leaf maple, coast live oak, and redwood). Bay leaves were sorted into three categories based on color and the condition of the cuticle. Those leaves designated as green or yellow appeared to have entered the stream when green or yellow, based on the condition of having an intact cuticle and remaining patches with green or yellow color-even if, in many cases, a substantial portion of the surface was marked by dark-brown to black necrotic tissue. Leaves designated as brown suggested reddish-brown oxidative discoloration of leaf pigments 
and had a rough surface, indicating the degradation of the cuticle. Brown leaves were classified as completely necrotic, whether lesions were apparent or not. Collected litter was surface sterilized as described above within $24 \mathrm{~h}$ of collection, and stored wrapped in a paper towel inside of a sealed plastic bag at $4^{\circ} \mathrm{C}$. Isolations on selective PARP-H medium using the "mosaic" sampling approach were attempted within 30 days of collection, typically within 2 weeks. Phytophthora spp. were identified as described above.

Colonization of and persistence on leaves. The preceding experiments showed that there were differences of trophic specialization between $P$. ramorum and stream-resident clade 6 Phytophthora spp. but, nevertheless, a significant portion of naturally occurring bay leaf litter in streams was colonized by both taxa. To see how leaves were colonized by these Phytophthora taxa upon immersion, how long they could persist on decomposing leaves, and whether $P$. ramorum had an advantage on leaves that it had infected in the canopy prior to their being exposed to saprotrophic organisms in streams, we conducted experiments wherein we deployed green bay leaves into streams and evaluated the extent of their colonization by $P$. ramorum and clade 6 Phytophthora spp. during their progressive decomposition over 16 weeks. Experiments were conducted in streams at Jack London State Historic Park and Fairfield Osborne Preserve, described above and hereafter referred to as the "redwood" and "mixed-evergreen" forest sites, respectively. A randomized complete block design was used, with five pools at each stream, set at least $100 \mathrm{~m}$ apart, serving as blocked replication points and leaf $P$. ramorum infection status and time of incubation in stream as treatment factors. A full implementation at each of the two sites served for one experimental replication. Experimental units consisted of packets (a flat envelope of $1 \mathrm{~mm}$ plastic mesh approximately 20 by $20 \mathrm{~cm}$ ) of 10 leaves packed so that the leaf surfaces were in minimal contact with one another and sealed by folding over the open lip and securing it with two common metal staples. These were incubated together, submerged in stream pools, inside a large nylon mesh sack.

Bay leaves infected with $P$. ramorum (identified by typical symptoms) or free of any necrosis (as indication of no Phytophthora infection) were collected from trees on site for each location and included in P. ramorum preinfected or Phytophthora-free leaf treatments, respectively. Fifty-leaf subsamples of the asymptomatic leaves and leaves with typical symptoms of $P$. ramorum infection were isolated on PARP medium using mosaic sampling and confirmed to be free from Phytophthora spp. or to be infected with $P$. ramorum only (at an average \pm standard deviation of approximately $13 \pm 16 \%$ of sampled discs per leaf), respectively. Packets of each leaf type were sampled at weeks 1 through 4, 6, 8, 12, and 16 weeks to be tested for Phytophthora colonization. Upon retrieval and transport to the laboratory in a chilled cooler, leaves were gently rubbed free of biofilm and surface sterilized (1\% household bleach, hypochlorite at $\sim 65 \mathrm{ppm}$, for 3 to $5 \mathrm{~min}$ ), then wrapped in a paper towel and stored in sealed plastic bags at $4^{\circ} \mathrm{C}$ until isolations could be performed. Isolations were attempted from all leaves belonging to treatment (a single packet) using mosaic sampling on PARP-H medium. Isolations from each collection were performed within 4 weeks, mostly within 2 weeks. The effect of storage period included as a covariate in the model did not influence treatment results significantly $(P=0.3907)$ (Supplementary Table S1). Phytophthora taxa were identified by morphological characteristics under magnification, as described above. The accuracy of morphological identification was validated by ITS sequence BLAST matches in GenBank for 135 representative isolates (Aram 2017).

To determine whether leaves were conducive to sporulation of Phytophthora spp. throughout the decomposition experiment, leaf remainders after isolations were placed in moist chambers (transparent crisper boxes) in growth chambers at $18^{\circ} \mathrm{C}$ and a $12 \mathrm{~h}$ photoperiod (approximately 1,800 lux) for 2 to 5 days, then flooded with deionized water and baited with two rhododendron leaves (Rhododendron catawbiense 'Boursault') separated from the samples using a plastic grid (styrene lighting panels, $15 \mathrm{~mm}$ grid size, $1 \mathrm{~mm}$ wide by $9 \mathrm{~mm}$ high) for 5 to 7 days. The moist chamber and baiting treatment was repeated once for each sample for a total of two baiting attempts. On retrieval, bait leaves were surface sterilized and mosaic isolations attempted from the baits within 2 days, as described above. Though bay leaf remainders were stored at $4^{\circ} \mathrm{C}$ for 40 to 88 days prior to treatment in moist chambers, both $P$. ramorum and clade 6 Phytophthora spp. were successfully baited from most of the samples notwithstanding differences in storage time. Though Phytophthora spp. recovery from baits was lowest at weeks 6 and 8, when the duration of storage was also the longest (74 to 88 days), these were also the collections for which direct recovery in culture was reduced for both taxa at one site (see Results, below). Number of days of storage prior to baiting was not significant as a covariate in the model $(P=0.4821)$ (Supplementary Table S2).

To determine the rate of decomposition, measured as leaf biomass loss, additional mesh packets with 10 leaves, preweighed to the hundredth decimal point of a gram with an analytical balance (model EP612C; Ohaus Corporation) and labeled using aluminum tree tags, were deployed in the same mesh sack and sampled at 2, 4, 8,12 , and 16 weeks. The original dry weight of leaves was estimated from their fresh weight based on the mean dry biomass (determined after oven drying at 55 to $60^{\circ} \mathrm{C}$ for $48 \mathrm{~h}$ ) of a subsample of 50 leaves for each leaf type $(51 \pm 2.5 \%$ dry biomass over both leaf types and sites). Thus, a total of 36 leaf packets was deployed at each replication pool. New packets were added at each collection to maintain the relative biomass.

Stream temperatures were recorded hourly using iButton loggers (Maxim Integrated, Inc.), sealed with a thin layer of silicon caulk and deployed inside a small, sealed plastic bag in the mesh sack at each block. The experiments were initiated 20 April and concluded 10 August 2013.

Analysis. In experiments testing trophic adaptation based on live and dead rhododendron leaf baits, leaf colonization by $P$. ramorum and $P$. gonapodyides or clade 6 Phytophthora spp. differed by very clear margins and, therefore, we present the data simply as the percentage of total number of samples that were colonized-either whole bait leaves or leaf discs, as indicated. We present the colonization of naturally occurring bay leaf litter in streams as the total number of leaf discs colonized out of the total number tested as an estimate of the total leaf area tested, because the unevenness of sampling for different leaf types and the magnitude of overall leaf-to-leaf variation in size and in colonization preclude conclusive statistical analysis.

In the experiment examining colonization and persistence of Phytophthora spp. on decomposing leaves, we determined the proportion of leaf discs producing either P. ramorum or clade 6 Phytophthora spp. in culture for each leaf and averaged results for each packet. This average leaf fraction colonized per packet was transformed with a logit function to normalize variances (Warton and Hui 2011). We analyzed the transformed Phytophthora recovery data using a linear mixed model (lme function) with the nlme package (Pinheiro et al. 2016) in R statistical software, version 3.3.1 (R Core Team 2015). Experimental block and packet (because both Phytophthora taxa were sampled from the same leaves) were set as random variables, with packet nested in block. Because Phytophthora spp. recovery followed a complex, nonlinear trend with respect to time, collection week was treated as a categorical variable. The normality of model residuals was verified by the Shapiro-Wilk test. $P$ values were obtained using the anova function in R with sum of squares set to type III ("marginal"). Least-square means comparisons were obtained with the lsmeans function of the lsmeans package (Lenth 2016). Significance for means comparisons was tested with a Bonferroni correction (applied to a $P=0.05$ significance threshold). The same course of analysis was followed for colonization of bait leaves.

For leaf decomposition, we estimated a decay constant $(k)$ for each block, leaf, and site combination based on the fraction of 
estimated original leaf mass remaining at each collection interval (Adair et al. 2010; Bärlocher 2005). For this, we used the exponential decay equation $M_{\mathrm{t}}=M_{0} \times e^{-k t}$, where $t$ is time as the number of days incubated in stream, $M_{\mathrm{t}}$ is the fraction of leaf mass remaining at each collection interval, and $M_{0}$, the fraction at time zero, is set to 1 (Adair et al. 2010; Bärlocher 2005). Values for $k$ were estimated using the $n l s$ function in the R statistical program. The decay constants were then analyzed in a mixed model using the lme function of the nlme package (Pinheiro et al. 2016), with site and leaf as predictive factors and block as a random factor.

\section{RESULTS}

Trophic specialization. We recovered P. ramorum from $73 \%$ of 240 fresh, live rhododendron leaves deployed in streams but from only 8 and $2 \%$ of leaves with tissues killed by freezing or drying, respectively (Table 1). In contrast, clade 6 Phytophthora spp. were recovered from approximately $60 \%$ of all leaf treatments. The results of laboratory experiments with the same leaf treatments were similar. Although P. ramorum could colonize dead leaf tissue when inoculated alone, the extent of colonization was considerably lower relative to that on fresh, live leaves (Table 2). The opposite was true for $P$. gonapodyides, which colonized dead leaves more effectively than live ones. The contrast was somewhat enhanced in combined inoculations with both $P$. ramorum and $P$. gonapodyides (Table 2). Results were similar for the higher inoculum rate, with generally higher levels of colonization (Supplementary Table S3).

Leaf litter survey. We isolated both $P$. ramorum and clade 6 Phytophthora spp. from naturally occurring bay leaf litter in streams, including green and yellow leaves with mostly necrotic tissue, and even from brown leaves that did not appear to have any living tissue remaining (Table 3). Both Phytophthora taxa were slightly less frequently isolated from brown leaves compared with green and yellow leaves. Clade 6 Phytophthora spp. were more frequently recovered from highly necrotic green and yellow leaves, whereas $P$. ramorum occurred at similar levels on green and yellow leaves regardless of the level of necrosis. In general, recovery of

TABLE 1. Incidence of colonization by Phytophthora ramorum or streamresident clade 6 Phytophthora spp. on fresh, live Rhododendron leaves or those killed by freezing or drying

\begin{tabular}{lcc}
\hline & \multicolumn{2}{c}{ Colonization $(\%)^{\mathrm{a}}$} \\
\cline { 2 - 3 } Bait type & P. ramorum & Clade 6 Phytophthora spp. \\
\hline Fresh & 73 & 60 \\
Frozen & 8 & 60 \\
Dried & 2 & 59 \\
\hline
\end{tabular}

a Percentage of a total of 240 of each bait leaf type deployed for 10 to 24 days in two northern California forest streams.

TABLE 2. Extent of colonization by Phytophthora ramorum and P. gonapodyides of fresh, live Rhododendron leaves or those killed by freezing or drying

\begin{tabular}{llcc}
\hline & & \multicolumn{2}{c}{ Colonization $(\%)^{\mathrm{a}}$} \\
\cline { 3 - 4 } Inoculation & Bait type & P. ramorum & P. gonapodyides \\
\hline P. ramorum only & Fresh & 41 & $\ldots$ \\
& Frozen & 15 & $\ldots$ \\
& Dried & 6 & $\ldots$ \\
P. gonapodyides only & Fresh & $\ldots$ & 8 \\
& Frozen & $\ldots$ & 50 \\
Both Phytophthora & Dried & $\ldots$ & 0 \\
spp. combined & & & 78 \\
& Fresh & 68 & 58
\end{tabular}

a Percentage of 192 total leaf discs sampled from 24 of each leaf type, pooled for two experiments in which the leaves were exposed for 10 days to each species separately or in combined inoculations in cups of water. these Phytophthora taxa from naturally occurring bay leaf litter in streams varied greatly by site (Supplementary Table S4). Overall, the regular recovery of both $P$. ramorum and clade 6 Phytophthora spp. showed that both taxa colonized and could potentially persist on naturally occurring bay leaf litter in streams. Both taxa were also recovered from white alder and madrone leaf litter, and clade 6 Phytophthora spp. were somewhat less frequently recovered from coast live oak leaves (data not shown); however, bay leaf litter was both most common and most regularly colonized by these Phytophthora taxa at these sites.

Persistence on decomposing leaves. In experiments testing Phytophthora persistence on decomposing bay leaves in streams, leaf decomposition during the 16-week interval of incubation in the streams proceeded in an approximately linear fashion at both sites (Fig. 1). Leaves in the redwood forest stream decomposed faster than those in the mixed-evergreen forest stream $(P=0.0035)$ (Supplementary Table S5). Leaves preinfected with $P$. ramorum and Phytophthora-free leaves decomposed at the same rate ( $k$ approximately 0.105) (Supplementary Table S6). Average daily stream temperatures ranging from approximately 12 to $18^{\circ} \mathrm{C}$ were similar at both sites, except that peak temperatures that occurred in July at both sites were notably higher at the redwood forest site (Fig. 2).

Mosaic isolations showed that both $P$. ramorum and clade 6 Phytophthora spp. colonized bay leaves rapidly, with 50 to more than $70 \%$ of the leaf area colonized within the first 3 weeks (Fig. 3). Identification of a subsample of isolates based on ITS sequences indicated that nearly all clade 6 Phytophthora spp. were either $P$. gonapodyides or P. chlamydospora (Aram 2017). P. ramorum colonization peaked in the first week at both sites but quickly declined thereafter; nonetheless, it persisted at low levels throughout the 16-week experiment. The slight increase in the proportion of leaf discs colonized by $P$. ramorum at the two last collections at the redwood forest site reflect a constant recovery of the pathogen from leaves that were increasingly reduced in area relative to previous samplings due to erosion of decomposing tissues (Supplementary Fig. S2).

In comparison, colonization of bay leaves by clade 6 Phytophthora spp. peaked at 3 weeks of in-stream incubation but reached higher levels than that of $P$. ramorum and generally persisted at higher levels throughout the experiment (Fig. 3; Supplementary Table S7). As leaves in the redwood forest stream lost up to $90 \%$ of their biomass by the final collection at 16 weeks, clade 6 Phytophthora spp. colonization of the leaves declined from more than $75 \%$ to similar levels as $P$. ramorum at approximately $25 \%$. In contrast, at the mixed-evergreen forest stream where leaf decomposition was slower, clade 6 Phytophthora spp. persisted at more than $75 \%$ while P. ramorum levels were less than $10 \%$, even up to the last collection. At the redwood forest site, the recovery of clade 6 Phytophthora spp. at week 6 was much lower than that at week 8 and closer to $P$. ramorum levels, interrupting the general trend of relatively higher recovery for the former taxa (Fig. 3). This sampling point corresponded to isolation plates often being overgrown by Pythium-like taxa, most of which were identified by ITS sequences as Phytopythium (Aram 2017), and may indicate

TABLE 3. Extent of Phytophthora ramorum or clade 6 Phytophthora spp. recovery from naturally occurring California bay leaf litter collected from forest streams and classified as brown, yellow, or green based on color and cuticle integrity, and as low $(<50 \%)$ or high $(\geq 50 \%)$ necrosis, shown as percentage of total leaf discs colonized from all of the leaves sampled

\begin{tabular}{lcccccc}
\hline & & \multicolumn{2}{c}{ Recovered $(\%)$} & & \multicolumn{2}{c}{ Number of } \\
\cline { 3 - 4 } $\begin{array}{l}\text { Leaf } \\
\text { type }\end{array}$ & Necrosis & P. ramorum & $\begin{array}{c}\text { Clade } 6 \\
\text { Phytophthora } \text { spp. }\end{array}$ & & Discs & Leaves \\
\hline Brown & High & 18 & 17 & 314 & 39 \\
Yellow & High & 26 & 23 & & 198 & 24 \\
Yellow & Low & 24 & 15 & & 153 & 22 \\
Green & High & 25 & 23 & & 180 & 26 \\
Green & Low & 21 & 13 & 699 & 90 \\
\hline
\end{tabular}


the suppression of Phytophthora spp. in culture due to competition from faster-growing organisms. Although hymexazol inhibits many Pythium sensu lato species, some, especially Phytopythium spp., are able to grow on PARP-H medium (Brazee et al. 2016; Erwin and Ribeiro 1996; Hüberli et al. 2013; Shrestha et al. 2013).

$P$. ramorum colonization of preinfected leaves was slightly but consistently higher than that of initially Phytophthora-free leaves at all collections, and the contrast of Phytophthora-free and preinfected leaves was highly significant $(P<0.0001)$. At the mixed-evergreen site, $P$. ramorum recovery from originally Phytophthora-free bay leaves fell to less than $5 \%$ by the second week and was near nil after that, though never completely absent from all samples. A similarly low level of $P$. ramorum recovery from originally Phytophthora-free leaves was also observed at the redwood forest site, though less pronounced. Clade 6 Phytophthora spp. colonization did not differ between Phytophthora-free leaves and those preinfected with P. ramorum (Fig. 3; Supplementary Table S8).

Baiting from postisolation leaf remainders produced both Phytophthora taxa throughout the 16 weeks, though the level of bait colonization varied by site, week, and Phytophthora taxon (Fig. 4). In the first 4 weeks, bait colonization paralleled colonization levels seen in isolations from leaves. For collections at weeks 6 and 8, baiting recovery of both Phytophthora taxa was close to nil, except for $P$. ramorum from preinfected leaves, which was slightly higher than that of clade 6 Phytophthora spp. at the redwood forest site at week 6 and much higher at the mixed-evergreen site at weeks 6 and 8. Though not significant in the overall model, from week 6 onward, P. ramorum sporulation from preinfected leaves from the mixed-evergreen site remained relatively constant at notably higher levels than that of clade 6 Phytophthora spp. or that of P. ramorum from originally Phytophthora-free leaves (Fig. 4). For the redwood forest site, baiting of $P$. ramorum from both leaf types increased from week 8 to 12, while baiting recovery of clade 6 Phytophthora spp. remained very low for the last two collections. In general, $P$. ramorum bait colonization occurred at a higher level than that of clade 6 Phytophthora spp. relative to their respective levels of colonization of bay leaves (Figs. 3 and 4).

\section{DISCUSSION}

In this study, we have demonstrated clear differences in trophic specialization between $P$. ramorum and stream-resident clade 6 Phytophthora spp. and, specifically, $P$. gonapodyides. In both stream and laboratory trials, $P$. ramorum demonstrated a very limited capacity to colonize rhododendron leaves that had been killed by freezing or drying. In contrast, stream-resident clade 6

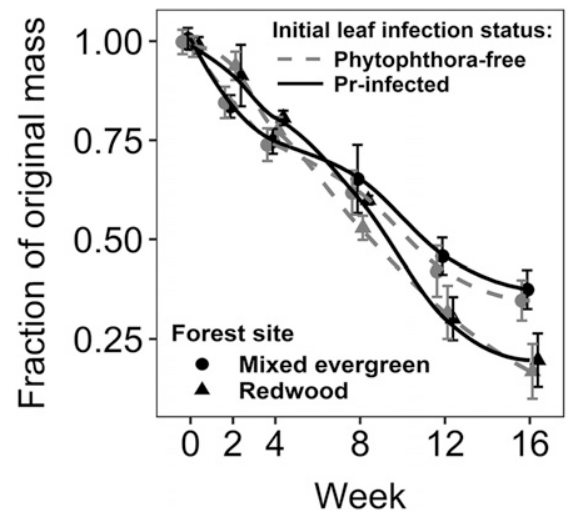

Fig. 1. Progress of decomposition as fraction of original mass remaining over 16 weeks for initially Phytophthora-free, green California bay leaves and leaves naturally preinfected with Phytophthora ramorum (Pr-infected) incubated in streams at a mixed-evergreen and a redwood forest site. Bars show \pm standard deviation.
Phytophthora spp. could readily colonize dead leaf tissue. Although $P$. gonapodyides seemed somewhat limited in colonizing live rhododendron leaves in laboratory inoculations, experiments in streamsas well as experience from baiting - suggest that stream-resident clade 6 Phytophthora spp. are generally able to colonize live leaf tissue as well. In laboratory experiments, the contrast was enhanced in combined inoculations of $P$. ramorum and $P$. gonapodyides, suggesting that a competitive advantage may be at play in initial colonization depending on the trophic specialization of each species. Also, successive colonization of necrotizing tissue may facilitate colonization by clade 6 Phytophthora spp. under natural stream conditions.

Nevertheless, $P$. ramorum and clade 6 Phytophthora spp. were recovered at similar levels from naturally occurring stream leaf litter of California bay, a common riparian species and one of the principal hosts for $P$. ramorum in coastal forests of California. Furthermore, bay leaves of varying degrees of senescence and decomposition, indicated by leaf color and necrosis, were colonized by both Phytophthora taxa, though clade 6 Phytophthora spp. were more common from more necrotic leaves. In light of this apparent inconsistency between the colonization of natural leaf litter and the distinct trophic specializations observed in experiments, especially in regard to $P$. ramorum, we hypothesized that $P$. ramorum may colonize freshly shed leaves in streams prior to their colonization by saprotrophic organisms, and that it may then be able to persist despite leaf decomposition and the increasing unsuitability of the tissue for its growth. Furthermore, in leaves that were infected in the canopy prior to entering the stream, $P$. ramorum could have an additional advantage in being present in leaves prior to their exposure to saprotrophic organisms, including clade 6 Phytophthora spp.

In fact, in the experiment testing the persistence of these Phytophthora taxa in decomposing leaves, the relatively more rapid colonization of leaves by $P$. ramorum on their initial exposure in streams suggests a competitive advantage on live plant tissue for the highly competent plant pathogen over clade 6 Phytophthora spp. However, clade 6 Phytophthora spp. achieved and maintained generally higher levels in the leaves for many weeks while $P$. ramorum levels declined rapidly after the first week. This indicates that the initial advantage for $P$. ramorum is short lived. This pattern is also consistent with the trophic specialization observed for each taxon in experiments with live and dead leaves, and the hypothesis of successive increase of clade 6 Phytophthora spp. in necrotizing tissue. It also implies that extended exposure of baits where clade 6 Phytophthora occur may result in the displacement of $P$. ramorum or other pathogens and a consequent failure of detection. Nevertheless, $P$. ramorum persisted and remained capable of considerable sporulation even when occurring at relatively low levels in substantially decomposed leaves. This observation may explain the regular recovery

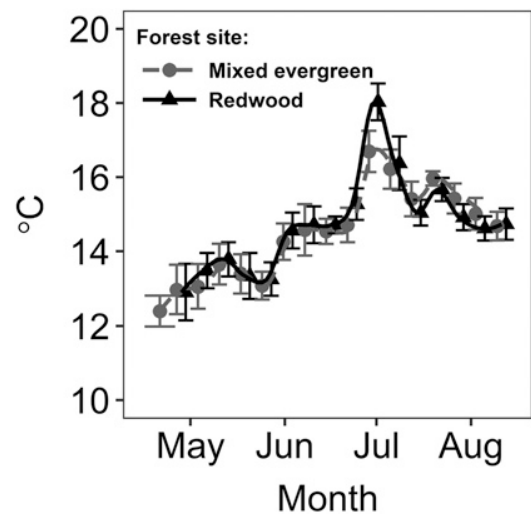

Fig. 2. Stream temperatures over the duration of the Phytophthora colonization and persistence in decomposing leaves experiment at a mixed-evergreen and a redwood forest site. Data points represent the weekly mean of hourly temperature recordings over 5 blocks at each site. Bars show \pm standard deviation. 
of $P$. ramorum from natural bay leaf litter, despite considerable necrosis and leaf decomposition.

Though preinfection of bay leaves by $P$. ramorum resulted in only a slightly higher level of its persistence in bay leaves, this could be a highly consequential difference. At the mixed-evergreen forest stream, sporulation from preinfected leaves was notably higher in later collection weeks than from initially Phytophthora-free leaves in which, by then, $P$. ramorum occurred minimally. This outcome was less apparent at the redwood forest site. However, at the latter site, $P$. ramorum was able to sporulate from highly decomposed leaves, often consisting of not much more than vascular tissue. Additionally, P. ramorum sporulation was greater than or similar to that of clade 6 Phytophthora spp. whereas its relative colonization of the leaves was usually much lower. $P$. ramorum produces abundant chlamydospores (Davidson et al. 2005); it is possible that the higher level of sporulation may reflect an ability of the pathogen to use energy stored in chlamydospores to produce sporangia and zoospores even though it is not actively able to grow in dead tissue. This fact may explain the significance of the preinfection advantage; the abundant colonization of bay leaves by $P$. ramorum in the first week of exposure may not persist long enough for chlamydospores to be formed in the tissue before the organism is displaced by saprotrophic competitors. However, it may be able to persist in the preinfected tissues where chlamydospores have already formed. Notably, though $P$. ramorum colonization in leaves rose to 50 to $75 \%$ of leaf area within the first week of exposure in streams, it ultimately receded to approximately the same initial levels in preinfected leaves (Fig. 1). However, P. ramorum colonized, persisted in, and sporulated from initially Phytophthora-free leaves, albeit at relatively lower levels in comparison with preinfected leaves. Although we found that both Phytophthora taxa were capable of sporulation under laboratory conditions from leaves through much of the 16-week incubation period, actual sporulation from colonized leaves in streams may depend on other environmental or biotic conditions.
The sporulation of both Phytophthora taxa was very low at weeks 6 and 8 and, at the redwood site, the recovery of clade 6 Phytophthora spp. in isolations at week 6 was also very low relative to the general colonization trend. Isolation plates for week 6 and 8 collections were also often overgrown by Phytopythium spp., either suppressing Phytophthora recovery entirely or sometimes obscuring conclusive identification and precluding effective subculturing. We did not attempt to quantify the occurrence of other oomycetes or fungi in this study but it is worth noting that interactions with other saprotrophic organisms, including aquatic hyphomycetes, may affect sporulation potential for these Phytophthora taxa. It may be that certain saprotrophs such as Phytopythium spp. dominate during certain stages of leaf decomposition. It is not obvious, however, why the suppression or overgrowing of Phytophthora spp. in culture was observed at one collection and at one site only. Decomposition proceeded at different rates at the two sites and a particular combination of factors may have contributed to the effect. Nonetheless, both Phytophthora taxa were sustained on decomposing bay leaves for 16 weeks, no doubt in the company of a great diversity of other saprotrophic organisms, including aquatic hyphomycetes. Marano et al. (2010) also regularly recovered both Phytophthora and Pythium sensu lato spp. from decomposing leaf litter-by baiting rather than direct isolation-over a similar timeframe.

Phytophthora spp. have generally been regarded as hemibiotrophic parasites, with an initial biotrophic phase followed by a shift to necrotrophy (Hardham and Blackman 2010; Hüberli et al. 2000; Lee and Rose 2010; Qutob et al. 2002; Tyler et al. 2006). Though the precision and usefulness of such characterizations may be limited (Oliver and Ipcho 2004), and though only a few Phytophthora spp. have been explicitly characterized as such, the fact that many Phytophthora spp. are known as primary causes of destructive plant diseases indicates that these organisms can colonize undamaged plant tissue and induce necrosis. We have shown here that, as has long been suspected (Brasier et al. 2003a;

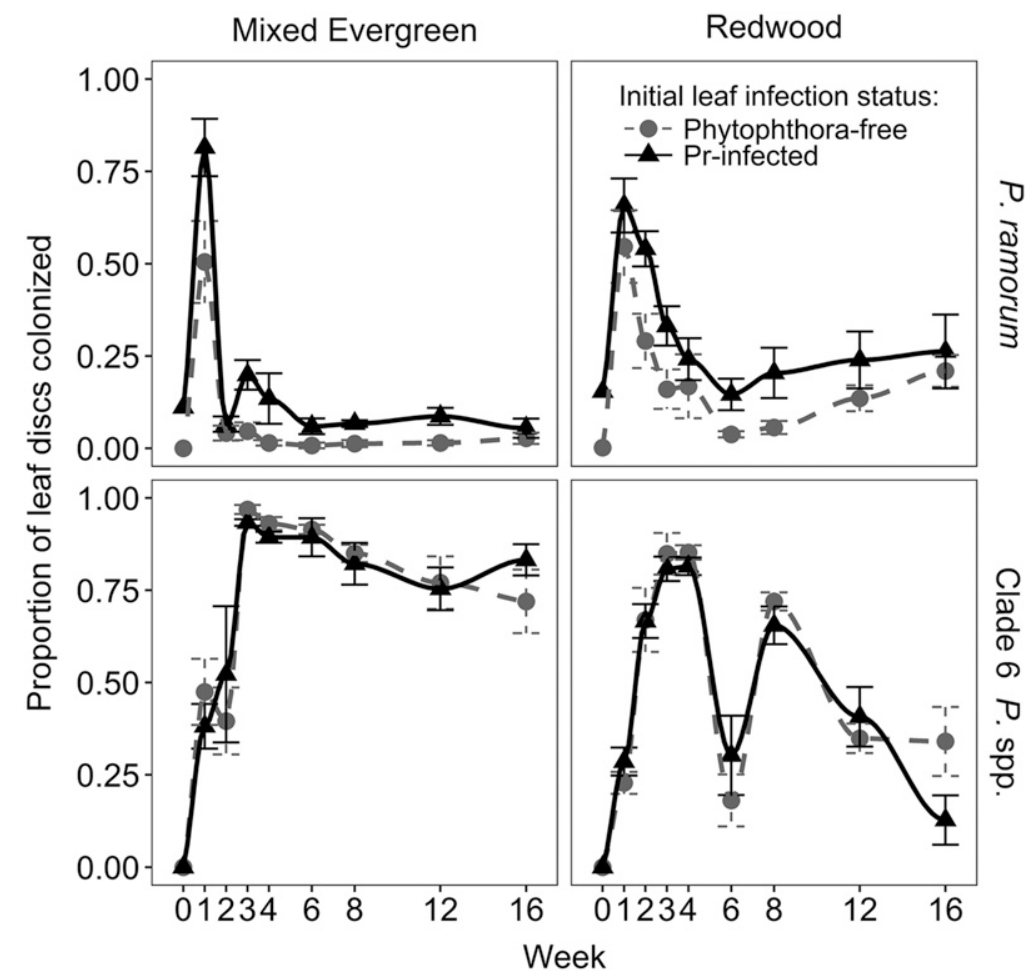

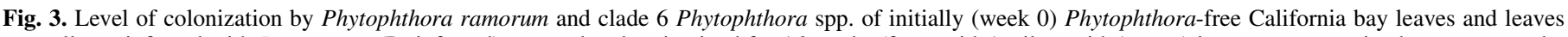

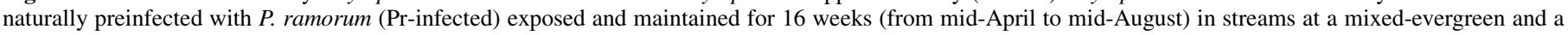

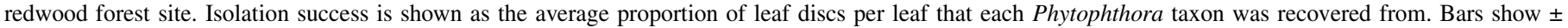
standard error. 
Hansen et al. 2012; Marano et al. 2016), some species in clade 6 stand as counterexamples to a narrow understanding of the genus as consisting exclusively of plant pathogens. For mycelial organisms, the evolutionary path from parasite to saprophyte has been considered (Cooke and Whipps 1980). To what extent the saprotrophic ability that characterizes clade 6 Phytophthora spp. occurs in other Phytophthora spp. or clades remains to be explored. Although we know many mycelial oomycetes as saprotrophs, only clade 6 Phytophthora spp. such as $P$. gonapodyides, P. chlamydospora, and P. lacustris (Nechwatal et al. 2013), among others, are Phytophthora spp. regularly associated with vegetative debris. Other members of this clade, such as P. megasperma and $P$. inundata, appear to have greater pathogenic tendencies (Brasier et al. 2003b; Erwin and Ribeiro 1996). Furthermore, many newly described species and yet undescribed taxa in clade 9 of the genus (Blair et al. 2008; Robideau et al. 2011) have been recovered from aquatic environments, primarily from nursery irrigation reservoirs but sometimes also from streams, especially in the eastern United States (Brazee et al. 2016; Hong et al. 2008, 2010, 2012; Yang and Hong 2013; Yang et al. 2014a,b). To date, these taxa have not been reported from decaying vegetation but it is possible that an aquatic and saprotrophically competent lifestyle may have evolved independently in this group. Similar to many stream-frequent clade 6 Phytophthora spp., they tend to be tolerant of high temperatures, though they may differ from this clade in demonstrating a clear capacity for sexual reproduction (Hong et al. 2012; MostowfizadehGhalamfarsa et al. 2008; Yang and Hong 2014). Indeed, there are indications, such as the occurrence of hybrids, that sexual reproduction may occur in some clade 6 species as well (Jung et al. 2011; Nagel et al. 2013; Stamler et al. 2016).

Interestingly, Bumbieris (1979) reported the saprotrophic competence of $P$. cryptogea, a species in clade 8 of the genus which includes many pathogens, including $P$. ramorum (Robideau et al. 2011). Morphological approaches to Phytophthora sp. identification have sometimes resulted in the misidentification of P. gonapodyides as P. cryptogea (Brasier et al. 2003a). The frequent isolation of a species identified as $P$. cryptogea from Australian waterways at approximately the same time (Taylor 1977) suggests that the isolate may, in fact, have been a clade 6 Phytophthora sp. Though $P$. gonapodyides is not frequently encountered in Australia, other clade 6 Phytophthora spp. with similar morphologies could be similarly misidentified (Dunstan et al. 2016; Jung et al. 2011). Alternatively, it is possible that species in other clades such as P. cryptogea also have saprotrophic competence and are abundant in certain aquatic ecosystems (Català et al. 2015; Dunstan et al. 2016). It may be useful to characterize the saprotrophic capacity of other Phytophthora spp. commonly encountered in aquatic environments by applying a simple assay based on the approach with live and dead leaves that we have demonstrated here.

The regular encounter with Phytophthora spp. associated with streams and vegetative litter in riparian areas during surveys has increased recognition of their potential role as decomposers in aquatic environments (Bärlocher et al. 2012; Hansen et al. 2012; Marano et al. 2016, 2010). Likewise, there is an interest in better understanding both evolutionary and phylogenetic connections between Phytophthora and related oomycete clades associated with vegetative litter in aquatic environments, such as Halophytophthora, Pythium sensu lato (especially Phytopythium), and the recently described Salisapiliaceae family (Hulvey et al. 2010b; Marano et al. 2016). Until recently, Halophytophthora spp. were the only taxa in the order Peronosporales to be studied as saprotrophs and decomposers in aquatic environments (Leaño et al. 1998; Marano et al. 2016; Newell 1996, 1992; Newell and Fell 1995). This genus, affiliated with Phytophthora but originally described from salt or brackish water environments, is under substantial revision in light of molecular studies (Hulvey et al. 2010b; Marano et al. 2016, 2014) and also because many isolates with DNA sequence affiliation with the clade have been recovered from fresh waters (Marano et al. 2016; Reeser et al. 2011; Yang and Hong 2014). Overall, phylogenetic studies have indicated that organisms throughout many branches of the oomycete evolutionary tree likely function as saprobes in diverse aquatic environments (Marano et al. 2016). Our

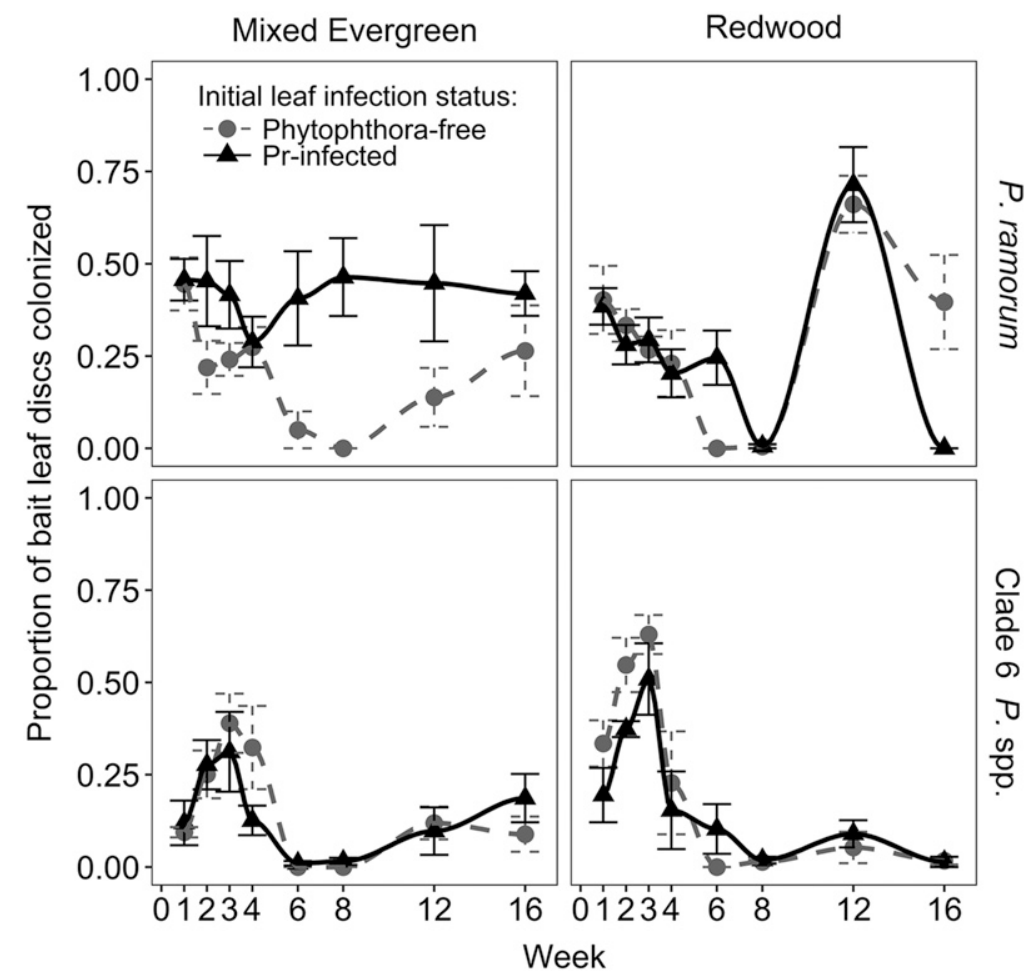

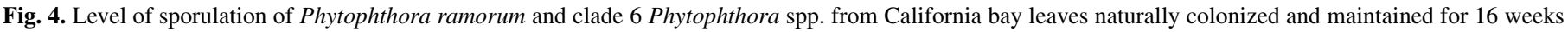

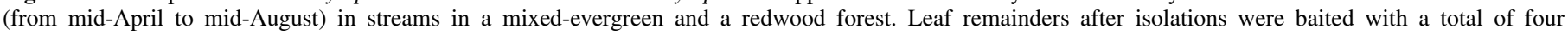

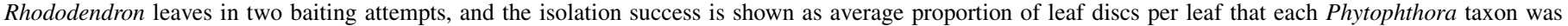
recovered from. Bars show \pm standard error. 
work confirms that certain clade 6 species of Phytophthora likely play a role as decomposers in surface waters.

As in the forest canopy, P. ramorum is an invader in streams. However, in contrast to the forest canopy, in streams it faces intense competition for suitable substrates with a multitude of saprotrophic organisms. Our results show that, although P. ramorum has a head start in colonizing leaves in streams, this advantage does not hold up in the long run. Clade 6 Phytophthora spp. and, presumably, other saprotrophs, are not interrupted or displaced from leaves and, in general, more of the vegetative debris in streams is likely to be available to them than to $P$. ramorum.

Nevertheless, at least on green California bay leaves, $P$. ramorum gains enough of a foothold to persist and, apparently, to sporulate for months. Green, live bay leaves are typically shed into streams during winter and spring storms when $P$. ramorum sporulation in the canopy is also most active (Davidson et al. 2005, 2008). Because these leaves are colonized in the stream, they likely provide the sporulation that sustains detection of $P$. ramorum inoculum in streams long after seasonal rains - and, therefore, sporulation in the canopy-have ceased. Newly introduced leaves will be subsequently colonized and can sustain the cycle into late summer. As the warm, dry season progresses in these forests, stream litter will decompose more rapidly, reducing the substrate on which $P$. ramorum can persist. Also, infected leaves in the forest canopy will be incrementally reduced due to shedding and the absence of new infections (Davidson et al. 2011) and, therefore, fewer preinfected leaves will be introduced into the stream. These facts may explain why $P$. ramorum persists in these forest streams for months after spring rains have ceased but eventually diminishes to very low levels by the fall (Murphy et al. 2005). The warming of streams late in the summer may additionally favor clade 6 Phytophthora spp. that are known to have higher optimal growth temperatures $\left(28\right.$ to $\left.30^{\circ} \mathrm{C}\right)$ than $P$. ramorum $\left(20^{\circ} \mathrm{C}\right)$ (Brasier et al. 2003a; Werres et al. 2001). Consistent with this, Eyre and Garbelotto (2015) found that dominant $P$. ramorum genotypes in an SOD-infested forest stream proliferated each spring and varied year by year. Additionally, much of the bay leaf litter that is shed into streams during the summer months is senescent (Cobb et al. 2013). The occurrence of both $P$. ramorum and clade 6 Phytophthora spp. on both yellow and brown natural bay leaf litter suggests that senescent leaves can be colonized as well as green leaves; however, this may also reflect leaves being colonized in the tree canopy prior to being shed as litter.

In general, the temperature range observed for these streams is typical for such perennial coastal streams that are fed by mountain springs and are mostly shaded by forest canopy. Although $P$. ramorum has an optimal growth temperature of approximately $20^{\circ} \mathrm{C}$ (Werres et al. 2001), it was not impeded by lower stream temperatures $\left(10\right.$ to $\left.16^{\circ} \mathrm{C}\right)$ early in the season. This conforms to the regular detection of this pathogen in California coastal forest streams in the late winter and early spring, when stream temperatures typically fall into this range (Murphy et al. 2005). Clade 6 Phytophthora, in contrast, generally have a much higher optimal growth temperature (approximately 28 to $30^{\circ} \mathrm{C}$ ) (Brasier et al. 2003a). Nevertheless, they are abundantly recovered from stream baits and litter throughout the year.

The occurrence of pathogenic Phytophthora spp. in streams and other surface waters raises concerns about the persistence and spread of these organisms. Unlike species such as $P$. alni sensu lato and $P$. lateralis, $P$. ramorum has not been associated with infections on submerged roots of riparian hosts. Other Phytophthora spp. recovered from streams with affinities to common agents of disease in agriculture such as $P$. cambivora, $P$. citrophthora, and $P$. syringae are recovered in areas with no obvious signs of disease, or the only incidence of disease is caused by other Phytophthora spp. (Greslebin et al. 2005; Hulvey et al. 2010a; Hwang et al. 2010; Reeser et al. 2011; Sims et al. 2015). Furthermore, P. ramorum often persists for years after known terrestrial sources have been eradicated (Chastagner et al. 2011, 2010; Sutton et al. 2009).
P. ramorum may survive long-term through chlamydospores, which are produced in large numbers in California bay leaf tissue (Davidson et al. 2005). In our study, in a few samples where decomposition had left only the leaf midrib intact, $P$. ramorum readily grew from this tissue whereas no clade 6 Phytophthora spp. were recovered. Bay leaves, of course, are especially conducive to $P$. ramorum colonization and sporulation (Davidson et al. 2005). Although we frequently found that litter from other tree species such as white alder, madrone, big leaf maple, and redwood were infected with both Phytophthora taxa, these types of leaf litter were neither as prevalent nor as extensively colonized at these sites (data not shown). It is possible that, in different geographical contexts, leaf litter from different plant species may favor different species of Phytophthora (Stamler et al. 2016).

Most research on $P$. ramorum in streams, including ours, has been done at sites where the pathogen is well established on canopy hosts, which implies regular introduction of exogenous inoculum into the stream, as well as the regular presence of host leaf and shoot litter (Eyre and Garbelotto 2015; Peterson et al. 2014a). However, $P$. ramorum has been recovered from streams where overstory hosts do not occur and, therefore, there may be other sources of inoculum (Chastagner et al. 2010, 2011; Sutton et al. 2009; Turner et al. 2008). In addition to leaf litter in streams, cryptic infections of riparian plant roots may represent another substrate that facilitates the survival and propagation of Phytophthora spp. in streams (Hansen et al. 2012; Marano et al. 2016). Our own preliminary surveys did not find $P$. ramorum infections on mostly herbaceous and some woody species occurring in streams, though other unidentified Phytophthora spp. were detected (unpublished data). Roots of alders have been extensively sampled in Oregon and some were infected with Phytophthora spp. such as $P$. chlamydospora, $P$. gonapodyides, and P. siskiyouensis (Sims et al. 2015). An extensive survey of roots of riparian trees in California would be appropriate. Studies have shown that plant roots can be infected by Phytophthora spp., including $P$. ramorum, without showing any symptoms (French-Monar et al. 2006; Loyd et al. 2014; Parke and Lewis 2007; Shishkoff 2011, 2007; Vercauteren et al. 2013; Widmer et al. 2012). This pathway may be especially important for Phytophthora spp. found in streams that do not readily colonize vegetative litter.

Notwithstanding its prevalence and persistence in streams, no outbreaks of $P$. ramorum on natural landscapes have ever been traced to an aquatic origin, and many studies have shown that spread through canopy infections is paramount in the natural spread of the pathogen (Eyre and Garbelotto 2015; Meentemeyer et al. 2011; Peterson et al. 2014a,b; Rizzo et al. 2005). General experience regarding the importance of Phytophthora inoculum in water for initiating epidemics is variable (Café-Filho et al. 1995; Loyd et al. 2014, 2014; Strnadová et al. 2010; Stukely et al. 2007; Tjosvold et al. 2008). Abundance of inoculum seems to be one important determinant. Remarkably, with the notable exceptions of pathogenic Phytophthora spp. with known riparian hosts such as $P$. alni sensu lato and $P$. lateralis, and $P$. cinnamomi in subterranean flowing water, there appear to be no records of a Phytophthora sp. pathogenic in forest or woodland canopies, such as $P$. ramorum or $P$. kernoviae, initiating an outbreak in a natural landscape, even locally, from inoculum originating from a body of water (Hansen et al. 2012). However, as long as virulent pathogens are present in water, such an outcome can never be ruled out (Hong and Moorman 2005; Tjosvold et al. 2008). The spread of $P$. capsici through a river system in Peru is perhaps suggestive of what is possible (HurtadoGonzáles et al. 2008).

In conclusion, California bay leaf litter is a suitable substrate for $P$. ramorum and clade 6 Phytophthora spp. such as $P$. gonapodyides in streams. Stream resident clade 6 Phytophthora spp. are clearly adapted as saprotrophs and likely play a role in the decomposition of vegetative litter in streams. In this capacity, though they seem to be initially outpaced by $P$. ramorum in colonization of fresh, live leaf litter, they may ultimately limit the relative abundance of the latter 
as they come to dominate dead and decomposing tissue. Thus, the introduction of $P$. ramorum into the streams of California's coastal forests does not seem to have affected the success of resident Phytophthora spp. in colonizing leaf litter and, in fact, the presence of such saprotrophic species may, to some extent, mitigate the pathogen's prevalence in streams. Nevertheless, $P$. ramorum's early colonization of leaves, whether originating in the canopy or in streams, allowed it to persist and remain capable of sporulation in streams over many months and through extensive leaf decomposition. Where hosts conducive to P. ramorum sporulation occur near streams, vegetative litter should be considered as a potential source of inoculum. Vegetative litter may also support other Phytophthora spp. in other stream ecosystems. Though there are few reports of plant infections originating from exposure to streamborne inoculum and no major disease outbreak has been associated with such a source, the presence of plant-pathogenic Phytophthora spp. in streams and other surface waters can never entirely be discounted as a potential source of inoculum. Understanding the ecology of Phytophthora spp. in such environments is important for effective thinking toward management strategies.

\section{ACKNOWLEDGMENTS}

We thank H. Mehl, A. Chen, G. Chio, V. Fontes, M. Jones, L. Li, K. Lew, and K. Spawton for technical assistance; R. Cobb and I. Pearse for valuable advice regarding decomposition analysis; and C. Freeman (California State Parks), S. Decoursey (Sonoma State University), and E. Stancil for site access and permitting.

\section{LITERATURE CITED}

Adair, E. C., Hobbie, S. E., and Hobbie, R. K. 2010. Single-pool exponential decomposition models: Potential pitfalls in their use in ecological studies. Ecology 91:1225-1236.

Aram, K. 2017. The ecology of Phytophthora ramorum and resident Phytophthora in California streams. Ph.D. thesis, University of California, Davis.

Balci, Y., Balci, S., Eggers, J., MacDonald, W. L., Juzwik, J., and Long, R. P. 2007. Phytophthora spp. associated with forest soils in eastern and northcentral US oak ecosystems. Plant Dis. 91:705-710.

Balci, Y., and Halmschlager, E. 2003a. Incidence of Phytophthora species in oak forests in Austria and their possible involvement in oak decline. For. Pathol. 33:157-174.

Balci, Y., and Halmschlager, E. 2003b. Phytophthora species in oak ecosystems in Turkey and their association with declining oak trees. Plant Pathol. 52:694-702.

Bärlocher, F. 2005. Leaf Mass Loss Estimated by Litter Bag Technique. Pages 37-42 in: Methods to Study Litter Decomposition. M. A. S. Graça, F. Bärlocher, and M. O. Gessner, eds. Online publication. Springer, The Netherlands. https://link.springer.com/chapter/10.1007/1-4020-3466-0_6

Bärlocher, F., and Boddy, L. 2016. Aquatic fungal ecology - How does it differ from terrestrial? Fungal Ecol. 19:5-13.

Bärlocher, F., Stewart, M., and Ryder, D. S. 2012. Processing of Eucalyptus viminalis leaves in Australian streams-Importance of aquatic hyphomycetes and zoosporic fungi. Fundam. Appl. Limnol. Arch. Hydrobiol. 179: 305-319.

Bjelke, U., Boberg, J., Oliva, J., Tattersdill, K., and McKie, B. G. 2016. Dieback of riparian alder caused by the Phytophthora alni complex: Projected consequences for stream ecosystems. Freshwater Biol. 61: 565-579.

Blair, J. E., Coffey, M. D., Park, S.-Y., Geiser, D. M., and Kang, S. 2008. A multi-locus phylogeny for Phytophthora utilizing markers derived from complete genome sequences. Fungal Genet. Biol. 45:266-277.

Brasier, C., and Webber, J. 2010. Sudden larch death. Nature 466:824-825.

Brasier, C. M. 2008. The biosecurity threat to the UK and global environment from international trade in plants. Plant Pathol. 57:792-808.

Brasier, C. M., Beales, P. A., Kirk, S. A., Denman, S., and Rose, J. 2005. Phytophthora kernoviae sp. nov., an invasive pathogen causing bleeding stem lesions on forest trees and foliar necrosis of ornamentals in the UK. Mycol. Res. 109:853-859.

Brasier, C. M., Cooke, D. E. L., Duncan, J. M., and Hansen, E. M. 2003 a. Multiple new phenotypic taxa from trees and riparian ecosystems in Phytophthora gonapodyides-P. megasperma ITS Clade 6 , which tend to be high-temperature tolerant and either inbreeding or sterile. Mycol. Res. 107: 277-290.
Brasier, C. M., Kirk, S. A., Delcan, J., Cooke, D. E. L., Jung, T., and Man In't Veld, W. A. 2004. Phytophthora alni sp. nov. and its variants: Designation of emerging heteroploid hybrid pathogens spreading on Alnus trees. Mycol. Res. 108:1172-1184.

Brasier, C. M., Sanchez-Hernandez, E., and Kirk, S. A. 2003b. Phytophthora inundata sp. nov., a part heterothallic pathogen of trees and shrubs in wet or flooded soils. Mycol. Res. 107:477-484.

Brazee, N. J., Wick, R. L., and Hulvey, J. P. 2016. Phytophthora species recovered from the Connecticut River Valley in Massachusetts, USA. Mycologia 108:6-19.

Bumbieris, M. 1979. Aspects of the biology of Phytophthora cryptogea. Aust. J. Bot. 27:11-16.

Bush, E. A., Hong, C., and Stromberg, E. L. 2003. Fluctuations of Phytophthora and Pythium spp. in components of a recycling irrigation system. Plant Dis. 87:1500-1506.

Café-Filho, A. C., Duniway, J. M., and Davis, R. M. 1995. Effects of the frequency of furrow irrigation on root and fruit rots of squash caused by Phytophthora capsici. Plant Dis. 79:44-48.

Català, S., Pérez-Sierra, A., and Abad-Campos, P. 2015. The use of genusspecific amplicon pyrosequencing to assess Phytophthora species diversity using eDNA from soil and water in northern Spain. PLoS One 10:e0119311.

Chastagner, G., Coats, K., Omdal, D., Ramsey-Kroll, A., and Elliott, M. 2011. Mystery on the Sammamish: What are the sources of Phytophthora ramorum infesting this Washington State waterway. (Abstr.) Phytopathology 101:S32.

Chastagner, G., Oak, S., Omdal, D., Ramsey-Kroll, A., Coats, K., Valachovic, Y. 2010. Spread of Phytophthora ramorum from nurseries into waterwaysImplications for pathogen establishment in new areas. Pages 22-28 in: Proc. Sudden Oak Death Fourth Sci. Symp. Gen. Tech. Rep. PSW-GTR229. U.S. Department of Agriculture, Forest Service, Pacific Southwest Research Station, Albany, CA.

Cobb, R. C., Eviner, V. T., and Rizzo, D. M. 2013. Mortality and community changes drive sudden oak death impacts on litterfall and soil nitrogen cycling. New Phytol. 200:422-431.

Cooke, D. E. L., Drenth, A., Duncan, J. M., Wagels, G., and Brasier, C. M. 2000. A molecular phylogeny of Phytophthora and related oomycetes. Fungal Genet. Biol. 30:17-32.

Cooke, R. C., and Whipps, J. M. 1980. The evolution of modes of nutrition in fungi parasitic on terrestrial plants. Biol. Rev. 55:341-362.

Cooper, W. S. 1971. The broad-sclerophyll vegetation of California. Pages 149-156 in: World Vegetation Types, The Geographical Readings series. S. R. Eyre, ed. Macmillan, London.

Croucher, P. J., Mascheretti, S., and Garbelotto, M. 2013. Combining field epidemiological information and genetic data to comprehensively reconstruct the invasion history and the microevolution of the sudden oak death agent Phytophthora ramorum (Stramenopila: Oomycetes) in California. Biol. Invasions 15:2281-2297.

Davidson, J. M., Patterson, H. A., and Rizzo, D. M. 2008. Sources of inoculum for Phytophthora ramorum in a redwood forest. Phytopathology 98: 860-866.

Davidson, J. M., Patterson, H. A., Wickland, A. C., Fichtner, E. J., and Rizzo, D. M. 2011. Forest type influences transmission of Phytophthora ramorum in California oak woodlands. Phytopathology 101:492-501.

Davidson, J. M., Wickland, A. C., Patterson, H. A., Falk, K. R., and Rizzo, D. M. 2005. Transmission of Phytophthora ramorum in mixed-evergreen forest in California. Phytopathology 95:587-596.

DiLeo, M. V., Bostock, R. M., and Rizzo, D. M. 2009. Phytophthora ramorum does not cause physiologically significant systemic injury to California bay laurel, its primary reservoir host. Phytopathology 99:1307-1311.

DiLeo, M. V., Bostock, R. M., and Rizzo, D. M. 2014. Microclimate impacts survival and prevalence of Phytophthora ramorum in Umbellularia californica, a key reservoir host of sudden oak death in northern California forests. PLoS One 9:e98195.

Dunstan, W. A., Howard, K., Stj. Hardy, G. E., and Burgess, T. I. 2016. An overview of Australia's Phytophthora species assemblage in natural ecosystems recovered from a survey in Victoria. IMA Fungus 7:47-58.

Erwin, D. C., and Ribeiro, O. K. 1996. Phytophthora Diseases Worldwide. American Phytopathological Society, St. Paul, MN.

Eyre, C. A., and Garbelotto, M. 2015. Detection, diversity, and population dynamics of waterborne Phytophthora ramorum populations. Phytopathology 105:57-68.

Eyre, C. A., Kozanitas, M., and Garbelotto, M. 2013. Population dynamics of aerial and terrestrial populations of Phytophthora ramorum in a California forest under different climatic conditions. Phytopathology 103:1141-1152.

Frankland, J. C. 1998. Fungal succession-Unravelling the unpredictable. Mycol. Res. 102:1-15.

French-Monar, R. D., Jones, J. B., and Roberts, P. D. 2006. Characterization of Phytophthora capsici associated with roots of weeds on Florida vegetable farms. Plant Dis. 90:345-350. 
Gessner, M. O., Chauvet, E., and Dobson, M. 1999. A perspective on leaf litter breakdown in streams. Oikos 85:377-384.

Ghimire, S. R., Richardson, P. A., Kong, P., Hu, J., Lea-Cox, J. D., and Ross, D. S. 2011. Distribution and diversity of Phytophthora species in nursery irrigation reservoir adopting water recycling system during winter months. J. Phytopathol. 159:713-719.

Greslebin, A. G., and Hansen, E. M. 2010. Pathogenicity of Phytophthora austrocedrae on Austrocedrus chilensis and its relation with mal del ciprés in Patagonia. Plant Pathol. 59:604-612.

Greslebin, A. G., Hansen, E. M., Winton, L. M., and Rajchenberg, M. 2005. Phytophthora species from declining Austrocedrus chilensis forests in Patagonia, Argentina. Mycologia 97:218-228.

Grünwald, N. J., Goss, E. M., and Press, C. M. 2008. Phytophthora ramorum: A pathogen with a remarkably wide host range causing sudden oak death on oaks and ramorum blight on woody ornamentals. Mol. Plant Pathol. 9: 729-740.

Hansen, E., and Delatour, C. 1999. Phytophthora species in oak forests of north-east France. Ann. For. Sci. 56:539-547.

Hansen, E. M. 2008. Alien forest pathogens: Phytophthora species are changing world forests. Boreal Environ. Res. 13:33-44.

Hansen, E. M., Goheen, D. J., Jules, E. S., and Ullian, B. 2000. Managing Port-Orford-cedar and the introduced pathogen Phytophthora lateralis. Plant Dis. 84:4-14.

Hansen, E. M., Reeser, P., Sutton, W., and Brasier, C. M. 2015. Redesignation of Phytophthora taxon Pgchlamydo as Phytophthora chlamydospora sp. nov. N. Am. Fungi 10:1-14.

Hansen, E. M., Reeser, P. W., Davidson, J. M., Garbelotto, M., Ivors, K. L., Douhan, G. 2003. Phytophthora nemorosa, a new species causing cankers and leaf blight of forest trees in California and Oregon, USA. Mycotaxon 88:129-138

Hansen, E. M., Reeser, P. W., and Sutton, W. 2012. Phytophthora beyond agriculture. Annu. Rev. Phytopathol. 50:359-378.

Hardham, A. R., and Blackman, L. M. 2010. Molecular cytology of Phytophthoraplant interactions. Australas. Plant Pathol. 39:29-35.

Hong, C., Gallegly, M. E., Richardson, P. A., Kong, P., and Moorman, G. W. 2008. Phytophthora irrigata, a new species isolated from irrigation reservoirs and rivers in Eastern United States of America. FEMS Microbiol. Lett. 285:203-211.

Hong, C., Richardson, P. A., Hao, W., Ghimire, S. R., Kong, P., and Moorman, G. W. 2012. Phytophthora aquimorbida sp. nov. and Phytophthora taxon "aquatilis" recovered from irrigation reservoirs and a stream in Virginia, USA. Mycologia 104:1097-1108.

Hong, C. X., Gallegly, M. E., Richardson, P. A., Kong, P., Moorman, G. W., and Lea-Cox, J. D. 2010. Phytophthora hydropathica, a new pathogen identified from irrigation water, Rhododendron catawbiense and Kalmia. Plant Pathol. 59:913-921.

Hong, C. X., and Moorman, G. W. 2005. Plant pathogens in irrigation water: Challenges and opportunities. Crit. Rev. Plant Sci. 24:189-208.

Huai, W-x.., Tian, G., Hansen, E. M., Zhao, W.-x., Goheen, E. M., Grünwald, N. J., and Cheng, C. 2013. Identification of Phytophthora species baited and isolated from forest soil and streams in northwestern Yunnan province, China. For. Pathol. 43:87-103.

Hüberli, D., Hardy, G. S. J., White, D., Williams, N., and Burgess, T. I. 2013. Fishing for Phytophthora from Western Australia's waterways: A distribution and diversity survey. Australas. Plant Pathol. 42:251-260.

Hüberli, D., Tommerup, I. C., and Hardy, G. E. S. J. 2000. False-negative isolations or absence of lesions may cause mis-diagnosis of diseased plants infected with Phytophthora cinnamomi. Australas. Plant Pathol. 29: 164-169.

Hulvey, J., Gobena, D., Finley, L., and Lamour, K. 2010a. Co-occurrence and genotypic distribution of Phytophthora species recovered from watersheds and plant nurseries of eastern Tennessee. Mycologia 102:1127-1133.

Hulvey, J., Telle, S., Nigrelli, L., Lamour, K., and Thines, M. 2010b. Salisapiliaceae-A new family of oomycetes from marsh grass litter of southeastern North America. Persoonia Mol. Phylogeny Evol. Fungi. 25: 109-116.

Hurtado-Gonzáles, O., Aragon-Caballero, L., Apaza-Tapia, W., Donahoo, R., and Lamour, K. 2008. Survival and spread of Phytophthora capsici in coastal Peru. Phytopathology 98:688-694.

Hwang, J., Jeffers, S. N., and Oak, S. W. 2010. Aquatic habitats-A reservoir for population diversity in the genus Phytophthora. Phytopathology 100: S150-S151.

Hwang, J., Oak, S. W., and Jeffers, S. N. 2011. Recovery of Phytophthora species from drainage points and tributaries within two forest stream networks: A preliminary report. N. Z. J. For. Sci. 41S:S83-S87.

Jules, E. S., Steenbock, C. M., and Carroll, A. L. 2015. Update on the 35-year expansion of the invasive root pathogen, Phytophthora lateralis, across a landscape of Port Orford cedar (Chamaecyparis lawsoniana) ed. A. Vannini. For. Pathol. 45:165-168.
Jung, T. 2009. Beech decline in Central Europe driven by the interaction between Phytophthora infections and climatic extremes. For. Pathol. 39:73-94.

Jung, T., Blaschke, H., and Oßwald, W. 2000. Involvement of soilborne Phytophthora species in Central European oak decline and the effect of site factors on the disease. Plant Pathol. 49:706-718.

Jung, T., and Blaschke, M. 2004. Phytophthora root and collar rot of alders in Bavaria: Distribution, modes of spread and possible management strategies. Plant Pathol. 53:197-208.

Jung, T., Cooke, D. E. L., Blaschke, H., Duncan, J. M., and Oßwald, W. 1999. Phytophthora quercina sp. nov., causing root rot of European oaks. Mycol. Res. 103:785-798.

Jung, T., Downing, M., Blaschke, M., and Vernon, T. 2007. Phytophthora root and collar rot of Alders caused by the invasive Phytophthora alni: Actual distribution, pathways, and modeled potential distribution in Bavaria. Alien Invasive Species Int. Trade 10:10-18.

Jung, T., Nechwatal, J., Cooke, D. E., Hartmann, G., Blaschke, M., and Oßwald, W. F. 2003. Phytophthora pseudosyringae sp. nov., a new species causing root and collar rot of deciduous tree species in Europe. Mycol. Res. 107:772-789.

Jung, T., Stukely, M. J. C., Hardy, G. E. S. J., White, D., Paap, T., and Dunstan, W. A. 2011. Multiple new Phytophthora species from ITS clade 6 associated with natural ecosystems in Australia: Evolutionary and ecological implications. Persoonia Mol. Phylogeny Evol. Fungi. 26:13-39.

Kroon, L. P., Brouwer, H., de Cock, A. W., and Govers, F. 2012. The genus Phytophthora anno 2012. Phytopathology 102:348-364.

Leaño, E. M., Vrijmoed, L. L., and Jones, E. G. 1998. Zoospore chemotaxis of two mangrove strains of Halophytophthora vesicula from Mai Po, Hong Kong. Mycologia 90:1001-1008.

Lee, S.-J., and Rose, J. K. C. 2010. Mediation of the transition from biotrophy to necrotrophy in hemibiotrophic plant pathogens by secreted effector proteins. Plant Signal. Behav. 5:769-772.

Lenth, R. V. 2016. Least-squares means: The R Package lsmeans. J. Stat. Softw. 69:1-33.

Loyd, A. L., Benson, D. M., and Ivors, K. L. 2014. Phytophthora populations in nursery irrigation water in relationship to pathogenicity and infection frequency of Rhododendron and Pieris. Plant Dis. 98:1213-1220.

Maloney, P. E., Lynch, S. C., Kane, S. F., Jensen, C. E., and Rizzo, D. M. 2005. Establishment of an emerging generalist pathogen in redwood forest communities. J. Ecol. 93:899-905.

Marano, A. V., Jesus, A. L., de Souza, J. I., Jerônimo, G. H., Gonçalves, D. R., and Boro, M. C. 2016. Ecological roles of saprotrophic Peronosporales (Oomycetes, Straminipila) in natural environments. Fungal Ecol. 19:77-88.

Marano, A. V., Jesus, A. L., de Souza, J. I., Leaño, E. M., James, T. Y., Jerônimo, G. H. 2014. A new combination in Phytopythium: P. kandeliae (Oomycetes, Straminipila). J. Fungal Biol. 5:510-522.

Marano, A. V., Pires-Zottarelli, C. L. A., Barrera, M. D., Steciow, M. M., and Gleason, F. H. 2010. Diversity, role in decomposition, and succession of zoosporic fungi and straminipiles on submerged decaying leaves in a woodland stream. Hydrobiologia 659:93-109.

Mascheretti, S., Croucher, P. J. P., Vettraino, A., Prospero, S., and Garbelotto, M. 2008. Reconstruction of the sudden oak death epidemic in California through microsatellite analysis of the pathogen Phytophthora ramorum. Mol. Ecol. 17:2755-2768.

Meentemeyer, R. K., Cunniffe, N. J., Cook, A. R., Filipe, J. A. N., Hunter, R. D., and Rizzo, D. M. 2011. Epidemiological modeling of invasion in heterogeneous landscapes: Spread of sudden oak death in California (1990-2030). Ecosphere 2:1-24.

Moralejo, E., Pérez-Sierra, A. M., Álvarez, L. A., Belbahri, L., Lefort, F., and Descals, E. 2009. Multiple alien Phytophthora taxa discovered on diseased ornamental plants in Spain. Plant Pathol. 58:100-110.

Mostowfizadeh-Ghalamfarsa, R., Cooke, D. E. L., and Banihashemi, Z. 2008. Phytophthora parsiana sp. nov., a new high-temperature tolerant species. Mycol. Res. 112:783-794.

Murphy, S. K., Lee, C., Valachovic, Y., Bienapfl, J., Mark, W., Jirka, A. 2005. Monitoring Phytophthora ramorum distribution in streams within California watersheds. Pages 409-411 in: Proc. Sudden Oak Death Third Symp.

Nagel, J. H., Gryzenhout, M., Slippers, B., Wingfield, M. J., Hardy, G. E. S. J., and Stukely, M. J. C. 2013. Characterization of Phytophthora hybrids from ITS clade 6 associated with riparian ecosystems in South Africa and Australia. Fungal Biol. 117:329-347.

Nagel, J. H., Slippers, B., Wingfield, M. J., and Gryzenhout, M. 2015. Multiple Phytophthora species associated with a single riparian ecosystem in South Africa. Mycologia 107:915-925.

Navarro, S., Sims, L., and Hansen, E. 2015. Pathogenicity to alder of Phytophthora species from riparian ecosystems in western Oregon. For. Pathol. 45:358-366.

Nechwatal, J., Bakonyi, J., Cacciola, S. O., Cooke, D. E. L., Jung, T., and Nagy, Z. Á. 2013. The morphology, behaviour and molecular phylogeny of Phytophthora taxon Salixsoil and its redesignation as Phytophthora lacustris sp. nov. Plant Pathol. 62:355-369. 
Nechwatal, J., and Mendgen, K. 2006. Widespread detection of Phytophthora taxon Salixsoil in the littoral zone of Lake Constance, Germany. Eur. J. Plant Pathol. 114:261-264.

Newell, S. Y. 1992. Autumn distribution of marine Pythiaceae across a mangrove-saltmarsh boundary. Can. J. Bot. 70:1912-1916.

Newell, S. Y. 1996. Established and potential impacts of eukaryotic mycelial decomposers in marine/terrestrial ecotones. J. Exp. Mar. Biol. Ecol. 200: 187-206.

Newell, S. Y., and Fell, J. W. 1995. Do halophytophthoras (marine Pythiaceae) rapidly occupy fallen leaves by intraleaf mycelial growth. Can. J. Bot. 73: 761-765.

O'Brien, P. A., and Hardy, G. E. S. J. 2014. Phytophthora cinnamomi in Western Australia. J. R. Soc. West. Aust. 97:47-55.

Oh, E., Gryzenhout, M., Wingfield, B. D., Wingfield, M. J., and Burgess, T. I. 2013. Surveys of soil and water reveal a goldmine of Phytophthora diversity in South African natural ecosystems. IMA Fungus 4:123-131.

Oliver, R. P., and Ipcho, S. V. S. 2004. Arabidopsis pathology breathes new life into the necrotrophs-vs.-biotrophs classification of fungal pathogens. Mol. Plant Pathol. 5:347-352.

Oudemans, P. V. 1999. Phytophthora species associated with cranberry root rot and surface irrigation water in New Jersey. Plant Dis. 83:251-258.

Parke, J. L., Knaus, B. J., Fieland, V. J., Lewis, C., and Grünwald, N. J. 2014. Phytophthora community structure analyses in Oregon nurseries inform systems approaches to disease management. Phytopathology 104:1052-1062.

Parke, J. L., and Lewis, C. 2007. Root and stem infection of rhododendron from potting medium infested with Phytophthora ramorum. Plant Dis. 91: 1265-1270.

Pérez-Sierra, A., López-García, C., León, M., García-Jiménez, J., Abad-Campos, P., and Jung, T. 2013. Previously unrecorded low-temperature Phytophthora species associated with Quercus decline in a Mediterranean forest in eastern Spain. For. Pathol. 43:331-339.

Peterson, E., Hansen, E., and Hulbert, J. 2014a. Source or sink? The role of soil and water borne inoculum in the dispersal of Phytophthora ramorum in Oregon tanoak forests. For. Ecol. Manage. 322:48-57.

Peterson, E., Hansen, E., and Kanaskie, A. 2014b. Spatial relationship between Phytophthora ramorum and roads or streams in Oregon tanoak forests. For. Ecol. Manage. 312:216-224.

Pinheiro, J., Bates, D., Sarkar, D., and R Core Team. 2016. nlme: Linear and Nonlinear Mixed Effects Models. R package, version 3.1-128. Online publication. https://cran.r-project.org/web/packages/nlme/index.html

Prospero, S., Grünwald, N. J., Winton, L. M., and Hansen, E. M. 2009. Migration patterns of the emerging plant pathogen Phytophthora ramorum on the west coast of the United States of America. Phytopathology 99:739-749.

Qutob, D., Kamoun, S., and Gijzen, M. 2002. Expression of a Phytophthora sojae necrosis-inducing protein occurs during transition from biotrophy to necrotrophy. Plant J. 32:361-373.

R Core Team. 2015. R: A Language and Environment for Statistical Computing. Online publication. R Foundation for Statistical Computing, Vienna. https://www.R-project.org/

Reeser, P. W., Sutton, W., Hansen, E. M., Remigi, P., and Adams, G. C. 2011. Phytophthora species in forest streams in Oregon and Alaska. Mycologia 103:22-35.

Rizzo, D. M. 2005. Exotic species and fungi: Interactions with fungal, plant and animal communities. Pages 857-877 in: The Fungal Community. 3rd ed. J. Dinghton, P. Oudemans, and J. White, eds. CRC Press, New York.

Rizzo, D. M., Garbelotto, M., and Hansen, E. M. 2005. Phytophthora ramorum: Integrative Research and Management of an Emerging Pathogen in California and Oregon Forests. Annu. Rev. Phytopathol. 43:309-335.

Roberts, P. D., Urs, R. R., French-Monar, R., Hoffine, M. S., Seijo, T. E., and McGovern, R. J. 2005. Survival and recovery of Phytophthora capsici and oomycetes in tailwater and soil from vegetable fields in Florida. Ann. Appl. Biol. 146:351-359.

Robideau, G. P., de Cock, A. W. A. M., Coffey, M. D., Voglmayr, H., Brouwer, H., and Bala, K. 2011. DNA barcoding of oomycetes with cytochrome c oxidase subunit I and internal transcribed spacer. Mol. Ecol. Resour. 11: 1002-1011.

Rundel, P. W., and Sturmer, S. B. 1998. Native plant diversity in riparian communities of the Santa Monica mountains, California. Madrono 45:93-100.

Shishkoff, N. 2007. Persistence of Phytophthora ramorum in soil mix and roots of nursery ornamentals. Plant Dis. 91:1245-1249.

Shishkoff, N. 2011. A test system to quantify inoculum in runoff from Phytophthora ramorum-infected plant roots. Phytopathology 101:1457-1464.
Shrestha, S. K., Zhou, Y., and Lamour, K. 2013. Oomycetes baited from streams in Tennessee 2010-2012. Mycologia 105:1516-1523.

Shreve, F. 1927. The Vegetation of a Coastal Mountain Range. Ecology 8: $27-44$

Sims, L. L., Sutton, W., Reeser, P., and Hansen, E. M. 2015. The Phytophthora species assemblage and diversity in riparian alder ecosystems of western Oregon, USA. Mycologia 107:889-902.

Stamler, R. A., Sanogo, S., Goldberg, N. P., and Randall, J. J. 2016. Phytophthora species in rivers and streams of the southwestern United States. Appl. Environ. Microbiol. 82:4696-4704.

Strnadová, V., Černỳ, K., Holub, V., and Gregorová, B. 2010. The effects of flooding and Phytophthora alni infection on black alder. J. For. Sci. 56: 41-46.

Stukely, M. J. C., Webster, J. L., Ciampini, J. A., Brown, E., Dunstan, W. A., and Hardy, G. E. S. J. 2007. Phytophthora inundata from native vegetation in Western Australia. Australas. Plant Pathol. 36:606-608.

Sutton, W., Hansen, E. M., Reeser, P. W., and Kanaskie, A. 2009. Stream monitoring for detection of Phytophthora ramorum in Oregon tanoak forests. Plant Dis. 93:1182-1186.

Taylor, P. A. 1977. Phytophthora spp. in irrigation water in the Goulburn Valley, Victoria. Aust. Plant Pathol. Soc. Newsl. 6:41-42.

Themann, K., Werres, S., Lüttmann, R., and Diener, H. A. 2002. Observations of Phytophthora spp. in water recirculation systems in commercial hardy ornamental nursery stock. Eur. J. Plant Pathol. 108:337-343.

Tjosvold, S. A., Chambers, D. L., Koike, S. T., and Mori, S. R. 2008. Disease on nursery stock as affected by environmental factors and seasonal inoculum levels of Phytophthora ramorum in stream water used for irrigation. Plant Dis. 92:1566-1573.

Turner, J., Jennings, P., Humphries, G., Parker, S., McDonough, S., Stonehouse, J. 2008. Natural outbreaks of Phytophthora ramorum in the UK-Current status and monitoring update. Pages 43-48 in: Proc. Sudden Oak Death Third Sci. Symp. Gen. Tech. Rep. PSW-GTR-214. Pacific Southwest Research Station, Forest Service, U.S. Department of Agriculture, Albany, CA.

Tyler, B. M., Tripathy, S., Zhang, X., Dehal, P., Jiang, R. H., and Aerts, A. 2006. Phytophthora genome sequences uncover evolutionary origins and mechanisms of pathogenesis. Science 313:1261-1266.

Vercauteren, A., Riedel, M., Maes, M., Werres, S., and Heungens, K. 2013. Survival of Phytophthora ramorum in Rhododendron root balls and in rootless substrates. Plant Pathol. 62:166-176.

Vettraino, A. M., Natili, G., Anselmi, N., and Vannini, A. 2001. Recovery and pathogenicity of Phytophthora species associated with a resurgence of ink disease in Castanea sativa in Italy. Plant Pathol. 50:90-96.

Voříšková, J., and Baldrian, P. 2013. Fungal community on decomposing leaf litter undergoes rapid successional changes. ISME J. 7:477-486.

Wallace, J. B., Eggert, S. L., Meyer, J. L., and Webster, J. R. 1999. Effects of resource limitation on a detrital-based ecosystem. Ecol. Monogr. 69: 409-442.

Warton, D. I., and Hui, F. K. 2011. The arcsine is asinine: The analysis of proportions in ecology. Ecology 92:3-10.

Werres, S., Marwitz, R., De Cock, A. W., Bonants, P. J., De Weerdt, M., and Themann, K. 2001. Phytophthora ramorum sp. nov., a new pathogen on Rhododendron and Viburnum. Mycol. Res. 105:1155-1165.

Werres, S., Wagner, S., Brand, T., Kaminski, K., and Seipp, D. 2007. Survival of Phytophthora ramorum in recirculating irrigation water and subsequent infection of Rhododendron and Viburnum. Plant Dis. 91:1034-1044.

Widmer, T. L., Shishkoff, N., and Dodge, S. C. 2012. Infectivity and inoculum production of Phytophthora ramorum on roots of eastern United States oak species. Plant Dis. 96:1675-1682.

Yakabe, L. E., Blomquist, C. L., Thomas, S. L., and MacDonald, J. D. 2009. Identification and frequency of Phytophthora species associated with foliar diseases in California ornamental nurseries. Plant Dis. 93:883-890.

Yang, X., Copes, W. E., and Hong, C. 2014a. Two novel species representing a new clade and cluster of Phytophthora. Fungal Biol. 118:72-82.

Yang, X., Gallegly, M. E., and Hong, C. 2014b. A high-temperature tolerant species in clade 9 of the genus Phytophthora: P. hydrogena sp. nov. Mycologia 106:57-65.

Yang, X., and Hong, C. 2013. Phytophthora virginiana sp. nov., a hightemperature tolerant species from irrigation water in Virginia. Mycotaxon 126:167-176.

Yang, X., and Hong, C. 2014. Halophytophthora fluviatilis sp. nov. from freshwater in Virginia. FEMS Microbiol. Lett. 352:230-237. 